\title{
Utilização e compreensão de preposições por crianças com distúrbio específico de linguagem $* * * *$
}

\author{
Use and comprehension of prepositions by children with specific \\ language impairment
}

\author{
Marina Leite Puglisi* (marinapuglisi@uol.com.br) \\ Debora Maria Befi-Lopes** \\ Noemi Takiuchi***
}

\section{*Fonoaudióloga. Especialista em Alterações no Desenvolvimento da Linguagem pelo Curso de Fonoaudiologia do Departamento de Fisioterapia, Fonoaudiologia e Terapia Ocupacional da Faculdade de Medicina da Universidade de São Paulo. \\ **Fonoaudióloga. Livre Docente em Fonoaudiologia pela Faculdade de Medicina da Universidade de São Paulo. Professora Associada do Departamento de Fisioterapia, Fonoaudiologia e Terapia Ocupacional da Faculdade de Medicina da Universidade de São Paulo. \\ ***Fonoaudióloga. Doutoranda em Semiótica e Lingüística Geral pela Faculdade de Filosofia, Letras e Ciências Humanas da Universidade de São Paulo. Professora Assistente do Curso de Fonoaudiologia da Faculdade de Ciências Médicas da Santa Casa de São Paulo. \\ *****Trabalho Realizado na Universidade de São Paulo.}

Artigo de Pesquisa

Artigo Submetido a Avaliação por Pares

Conflito de Interesse: não

Recebido em 30.08.2004. Revisado em 1.08.2005; 6.09.2005; 1.11.2005

Aceito para Publicação em 1.11.2005.

\begin{abstract}
Background: the ability of children with Specific Language Impairment (SLI) to use and comprehend closed-class words. Aim: acknowledging the increasing search for the characterization of linguistic performance of this population in different languages, as well as the findings of international literature that stress the difficulty of these children in using closed-class grammatical morphemes, the aim of this study was to analyze the performance of children with SLI in tests of production and comprehension of prepositions. The purpose of this research was also to compare the performance of these children to that of their typical language developing peers, in terms of the overall index of correct answers and the most frequent types of errors in both groups. Method: an objective test was developed in order to analyze production and comprehension of four types of prepositions that are used to establish the following semantic relations: with (company relation); by (way relation); in, on or at (place/position relations); and to (destination relation). This test was carried out with 19 SLI children and 29 typically developing children (CG - control group), one year younger than the research group. Results: SLI children presented the same pattern of results, although delayed, of children in the CG in the comprehension test. In the task involving production, however, the performance of SLI children was quantitatively and qualitatively inferior to their typical developing controls. This performance was mainly characterized by the omission of prepositions. Conclusion: the findings corroborate the view that grammatical words constitute a challenge for SLI children, since they presented many errors that suggest difficulties in the domain of prepositions. The results also emphasized, for the SLI group, deficits in the expressive language.
\end{abstract}

Key Words: Child Language; Language Development; Language Development Disorders.

\section{Resumo}

Tema: habilidade de crianças com Distúrbio Específico de Linguagem (DEL) em produzir e compreender palavras de classe fechada. Objetivo: tendo em vista a crescente busca pela caracterização do desempenho lingüístico desta população em diversas línguas, e os achados da literatura internacional que indicam a dificuldade destas crianças em utilizar as palavras de classe fechada, o objetivo deste estudo foi analisar a performance de crianças com DEL em provas de produção e compreensão de preposições. Também foi intuito deste trabalho comparar o desempenho destas crianças com o de crianças com desenvolvimento típico de linguagem quanto ao índice de acertos gerais e ao tipo de erros freqüentemente cometidos por ambos os grupos. Método: foi elaborado um teste objetivo a fim de analisar a produção e a compreensão de quatro tipos de preposições que estabelecem as seguintes relações semânticas: com (relação de companhia); de (relação de meio); na ou no (relação de lugar/posição); e para (relação de destino). Este teste foi aplicado a 19 crianças com DEL e a 29 crianças com desenvolvimento típico de linguagem grupo controle (GC), com idade inferior em um ano. Resultados: as crianças com DEL apresentaram resultados equiparáveis, embora atrasados, aos do GC na prova de compreensão de preposições. Na tarefa de produção de preposições, entretanto, as crianças com DEL demonstraram um desempenho quantitativa e qualitativamente inferior ao do GC, caracterizado, principalmente, pela omissão das preposições. Conclusão: os resultados confirmam as dificuldades relacionadas ao domínio das preposições pelas crianças com DEL, e evidenciam o maior prejuízo expressivo nesta patologia.

Palavras-Chave: Linguagem Infantil; Desenvolvimento da Linguagem; Transtornos do Desenvolvimento da Linguagem. 


\section{Introduction}

The term "Specific Language Impairment” (SLI) refers to children with difficulties in acquiring and developing language abilities in the absence of cognitive, physical and sensorial deficits, severe emotional impairments, harmful environmental factors and brain injuries (Bishop, 1992; StantonChapman et al., 2002; Corrêa et al., 2003). Even though there are no biological marks that justify the language deficits, there is some evidence of a determining genetic component in this pathology (Stanton-Chapman et al., 2002; Choudhury and Benasich, 2003; Bishop, 2003), even if of uncertain origin and location (O'Brien et al., 2003).

The diagnostic process of these children usually includes receptive and expressive language measures (Dale et al., 2003; CastroRebollledo et al., 2004). Although both tasks demand semantic and syntactic processing of the information, production involves sophisticated abilities of phonological processing, as well as a higher linguistic knowledge that allows the elaboration of new utterances (Bishop, 1992). With this respect, Kamhi (1998) had commented that children with SLI frequently present better abilities to comprehend phrasal structures than to produce them, and can even show satisfactory performance for their age in receptive language measures (usually in tasks that involve single words recognition, and not necessarily sentence comprehension).

The language difficulties showed by children with SLI are usually related to phonology (Bortolini and Leonard, 2000; Befi-Lopes and Palmieri, 2000; Befi-Lopes et al., 2003; Maillart et al., 2004), semantics (Tomasello, 2000; Befi-Lopes and Rodrigues, 2001; Windfuhr et al., 2002) and syntax (Bedore and Leonard, 2001; Fey et al., 2002; Grela et al., 2004; Wulfeck et al., 2004), in different levels. With development, and helped by speechlanguage therapy, these children usually improve their performance in some tasks, and can even migrate among the subtypes of SLI, according to the most affected language aspects (CrespoEguílaz and Narbona, 2003). According to the authors cited above, it's possible to understand that children with SLI have difficulties to comprehend the established relations between linguistic signs and their meanings, and to combine these elements in linguistic codes capable of passing on even more abstract knowledge. If children with SLI have difficulties in acquiring words that refer to concrete entities (McGregor et al., 2002), the task becomes even more challenging when it involves the acquisition of words with abstract meanings. Closed-class words (pronouns, articles, conjunctions) usually express syntactic functions, rather than semantic, and serve, mainly, as phrasal connection elements, with low semantic load of their own (Grela et al., 2004). The acquisition and use of such words constitute an especially difficult process for these children, for, opposite to the acquisition of nouns, verbs and adjectives, not only a semantic relation is necessary, but also a syntactic knowledge (Leonard et al., 1997).

Another group of words that constitutes the closed-class category is the group of prepositions. Prepositions only have meaning in the relation expressed among the elements to which they refer, since there is no ecstatic semantic content. That occurs because the same preposition, depending on how it's used in a sentence, can establish different semantic relations between the phrasal arguments. The meaning fickleness, allied to the fact that prepositions don't express the essential content of the message, promote a strong tendency to the omission of this grammatical class by children with SLI (Grela et al., 2004).

In English, it is possible that some specific prepositions associate to verbs to change them, attributing new meaning. In such contexts, they are no longer classified as prepositions but, rather, as verbal particles. Watkins and Rice (1991) studied the use of these words in both contexts by children with SLI, and concluded that they use prepositions similarly to typical developing children of the same linguistic age, but have worse performance in the use of verbal particles. Given that the phonological complexity of these words was exactly the same, since they had the same phonetic/acoustic structure, the authors concluded that SLI children are capable of recognizing the prepositions, but not the verbal particles, as a grammatical category, evidencing a syntactic-based deficit.

Grela et al. (2004) analyzed the use of dative ("give it to her") and locative ("put it in the box" and "put it on the table") prepositions by children with SLI. They observed that, opposite to the findings of Watkins and Rice (1991), the subjects showed greater difficulties in using these words than children in the control group. A possible explanation for this inconsistency is related to the type of verbs used in each study. In the initial study, conducted by Watkins and Rice (1991), prepositional phrases functioned independently 
of a set of intransitive verbs (e.g., walk over the chair, jump off the chair). In other words, the prepositional phrases functioned as adjuncts, and were not required by the verb. The verbal particles analyzed by the same authors, instead, not only were dependent on the verbs, but also changed their meanings. In the recent study conducted by Grela et al. (2004), the verbs used were indirect transitive, that is, necessarily demanded the preposition as part of the indirect object of the sentence. This semantic and syntactic dependence between verb and preposition could explain the worse performance of the research group. In short, if the difficulty of children with SLI refers to the comprehension of the relations between verbs and prepositions, it is natural that they would present more errors exactly when these relations should necessarily be expressed in words (Grela et al., 2004).

Still according to the same authors, locative prepositions, which's appearance is usually earlier because of the establishment of simpler cognitive relations (special position), are more easily produced by children with SLI than dative, instrumental or benefactive prepositions, which have more abstract meanings. Besides, the fact that these children showed more substitution than omission errors was a strong indicative that they comprehended the syntactic function of the prepositions, but were uncertain of the semantic relation involved between the verb and the indirect object (Grela et al., 2004).

Finally, it's also important to emphasize the role of the input in the acquisition of this class of words. Akhtar (1999) and Tomasello (2000) believe that grammatical acquisition is based in the comprehension, detainment and manipulation of phrasal structures used by the adults. From the moment that children hear the same sentence many times, they begin to build knowledge about its implicit meaning, as well as the type of phrasal structure used and, specifically, the thematic roles related to the verbs. In this way, to learn the appropriate use of prepositions, children would have to be able to memorize the sentences used by the adults and to associate the phrasal structures of these sentences to the characteristics of transitivity of the verbs used and to the cognitive/ semantic relations displayed by them. The complexity of these abilities makes children prefer to use, in the beginning of their development, sentences previously produced by adults, which's use do not demand children's spontaneous elaboration (King and Normington, 1999). Yet, it's necessary to observe if children with SLI keep using these types of sentences for a longer period during their development.

Given the growing search for the characterization of the linguistic performance of children with SLI, speakers of different languages, the objectives of this study were:

1. To analyze the performance of children with SLI (study group - SG), speakers of Brazilian Portuguese, and typical language developing children (control group - CG) in terms of production versus comprehension of prepositions. 2. To compare the performances of SLI children to those of CG children regarding general rate of correct answers and also rate of correct answers for each type of preposition, in both production and comprehension tasks.

3. To analyze the types of errors frequently presented by children with SLI, relating them to the most common errors of children from the CG.

The initial hypothesis of this study predicted that children with SLI would have more difficulty in dealing with prepositions than their typical developing peers, especially to produce it appropriately. Moreover, it was expected that SLI children would present mainly errors of substitution, instead of omission errors, pointing out a greater difficulty in establishing the semantic relations involved between verbs and prepositions.

\section{Methods}

\section{Participants}

This study was submitted to the analysis of the Research Commitee of the Department of Physical Therapy, Speech-Language and Hearing Science and Occupational Therapy of the School of Medicine of the University of São Paulo (USP), and approved, according to protocol number 283/ 03. All parents or caregivers previously read and signed the Free and Clear Consent Term, agreeing with the participation of the children in this study.

The sample comprised 19 children with diagnosis of Specific Language Impairment (SLI), with ages between 3 and 5 years. All subjects went through a complete language assessment and were in therapeutic process at the Speech-Language and Hearing Science Laboratory on Language Development and Language Impairment of the Speech-Language and Hearing Science Course of 
the School of Medicine of the University of São Paulo (USP).

Control group (CG) was composed by 29 children with ages varying from 2 to 4 years and without any complaints of language deficits. These children were recruited in a public kindergarten school located at the same geographic region of the University's Speech-Language Pathology and Audiology Clinic, and were referred by the caregivers for presenting typical language development. These children, after the indication, went through an informal observation with the researchers in order to verify their conversation abilities, speech intelligibility and orders comprehension. Four children (two with 2 years and two with 3 years-old) were excluded from the sample because they didn't have satisfactory performance in these tasks.

Subjects were divided in six subgroups:

\section{Study Group (SG)}

- group of 3-year-old SLI children $(n=6)$; . group of 4-year-old SLI children $(n=7)$; . group of 5-year-old SLI children $(n=6)$.

\section{Control Group (CG)}

- group of 2-year-old typically developing children $(n=10)$;

- group of 3-year-old typically developing children $(\mathrm{n}=10)$;

- group of 4-year-old typically developing children $(n=9)$.

Instruments and Procedure

Based on the studies carried out by Watkins and Rice (1991) and Grela et al. (2004), two protocols were developed - Prepositions' Production (PP) and Prepositions' Comprehension (PC) - in order to analyze the production and comprehension of four types of prepositions that establish the following semantic relations:

. with (company relation);

. by (mean relation);

. in, on or at (place/position relations); .to (destination relation).

Prepositions' Production (PP) Protocol (Appendix 1 and 2)

Action pictures that could express company, mean, place/position or destination relations, according to the phrasal context, were used to elicit the production of the prepositions. Twelve pictures were selected (three to evoke each preposition), and the first four served as pilots, in order for the child to get used to the task.

After the presentation of each action picture, the researcher began the description of the scene using simple period sentences with structures that demanded the use of an indirect object or an adjunct (preposition $(+$ article $)+$ noun $)$. The researcher ended the production of these sentences at the verb and the child was asked to complete the message (i.e. "the girl is playing... [with the dog]"). This procedure is believed to create an obligatory context for the production of the preposition, since the verb used in this specific context requires a verbal argument (preposition (+ article) + noun). At the end, each child had to complete eight sentences, two from each type of preposition.

Prepositions' Comprehension (PC) Protocol (Appendix 3 and 4)

It was prepared and used an album of pictures representing nouns related to different prepositions. Each board comprised four pictures: a person, related to the company preposition (with); a means of transportation, referring to the mean relation (by); an object, establishing a place/ position relation (in/on/at); and a picture of a place, in order to be related to the destination notion (to). The album displayed, at the end, 20 pictures (five referring to each preposition), and the first four served as pilots, in order for the child to get used to the task.

The researcher produced phrasal structures identical to those from the production task. In this task, however, she interrupted the emission right after the production of the preposition, and the child was encouraged to point out the picture that correctly represented the noun to which the preposition referred to (i.e. "the teacher sat at the... [chair]"). For each board, the child was supposed to point out only two pictures, in order to avoid correct answers by exclusion. Thus, there were always two target-pictures and two pictures that served as distracters in each board that composed the album. Each type of preposition was used by the researcher twice, in different contexts, totalizing eight answer requests for each child.

The test was carried out in the order cited above, with the production task preceding the comprehension task. All pictures were colorful, simple and clear, with digital quality. 
A pilot study was carried out before the beginning of the research, with typically developing children, in order to prove whether the tasks were appropriate to the purpose of the study. This procedure had the aim to guarantee that all children would understand the tasks. Even 2-yearold children (who were younger than the youngest children of the CG) demonstrated to understand the proper type of answer for each task (prepositions' production and comprehension), proving that the test was suitable to all children in the age range considered.

\section{Results}

Types of Analysis

At first, intra-group analysis were conducted in order to verify children performances through the years in both tasks. After that, children from the study group were paired to children from the control group one year younger. The description of the compared variables in each task follows, along with the respective quantitative and qualitative analysis:

\section{Prepositions' Production (PP) Protocol \\ Quantitative analysis:}

1.Types of answers - classified as intelligible, unintelligible (given the large proportion of children with phonologic deficits), or absent (when the child didn't say anything, didn't point to the picture or commented something was not related to the task). When intelligible:

2. Presence or absence of an obligatory context to the production of each preposition - in case the children completed the sentences with structures that did not demand the use of prepositions, preventing posterior analysis. Such answers, however, were syntactically and semantically appropriate (ex.: The boy is going... happily). In the presence of obligatory context:

3. Prepositions' use - children's responses were classified as correct or incorrect according to the following criteria:

$C$-EP-Correct answers with the use of the correct preposition.

$C$-AP - Correct answers with the use of another preposition - Ex.: The girl is playing... [of throwing the ball] (expected complement: with the dog). The description is correct because it's pertinent to the picture (in it, the girl is playing ball with the dog). I-NP - Incorrect answers (non pertinent to the picture), but syntactically appropriate - Ex.: The man is walking... [in the woods] (expected complement: with the dog). I-AP - Incorrect answers, although pertinent, with the use of another preposition - Ex.: The boy is going... [with the bicycle] (expected complement: by bicycle). $I-A$ - Incorrect answers, although pertinent, with substitution of the preposition by na article - Ex.: The boys are climbing... [the tree] (expected complement: on the tree).

$\mathrm{I}-\mathrm{O}$ - Incorrect answers, although pertinent, omitting the preposition - Ex.: The men are going... [church] (expected complement: to the church).

Qualitative analysis:

Each preposition was analyzed separately in order to verify whether existed a pattern of responses or not. Thus, the substitutions and correct answers for each preposition were described, quantified and compared.

\section{Prepositions' Comprehension (PC) Protocol}

Correct and incorrect answers were calculated for each type of preposition, and then separately analyzed regarding types of substitution. Interpretation of the substitutions observed the semantic relation between the object pointed out by the child and the sentence uttered by the researcher.

Data were statistically analyzed with the Proportion Iguality parametric technique. Significant differences could be detected only when p-values (values resulting from the comparisons) were inferior to 0,1 (such values were signaled with $*$, for better results view).

\section{Data Analysis}

The first analysis carried out was the comparison between production and comprehension abilities for each studied group, as shown in Table 1. The rate of correct answers was calculated with the subtraction of responses classified as "absence of obligatory context" from the total number of "possible answers", in so far as those responses were syntactically and semantically correct, but their structures did not demand the use of preposition. This measure was taken with the aim to do not underestimate the answers of children who did not produce this types 
of structures, since the production of the targetprepositions were not possible.

Children in the SG showed better prepositions' comprehension than production abilities (significant difference), as opposed to children in the $\mathrm{CG}$, who had very similar performances across both abilities. The performance of the CG increased with age in both tasks, while the SG showed increasing performance only in the comprehension task.

Analysis of the production task

At first, it was analyzed the types of answers produced by the children. In this way, the numbers of intelligible, unintelligible and absent responses were compared between SG and the CG of inferior age (Table 2).

Proportional differences between groups were considered statistically significant in all measures. Thus, children from the SG showed less intelligible answers than those from the CG in all ages, because of both unintelligible and absent responses.

Next, the rate of correct answers (C-EP) was compared between each $\mathrm{SG}$ and the respective $\mathrm{CG}$ (one year younger) (Table 3 ).

Children from the SG had a rate of correct answers significantly lower than those from the CG in all ages, even after 3 years-old, when the majority of their responses were intelligible.

To verify if the type of preposition influenced the performance of the children, SG and CG (one year younger) were compared regarding the rates of correct answers for each preposition used (Table 4). This analysis was not carried out with the younger subjects because 3 -year-old children from the SG had few intelligible answers, making impossible a representative statistical analysis.

In this way, the implicit lexical characteristics in the use of each preposition did not influence the performance of the children, given that the SG was worse than the CG in every analysis carried out (with significant difference between groups), except for the production of the prepositions "in/ on/at" and "to", in the comparison SG 4 years X CG 3 years. It's important to emphasize that none of the SG children was able to produce correctly the preposition "by".

Finally, the types of errors of children from the SG were compared to those of CG children (one year younger). For that purpose, the total number of other prepositions (I-AP), substitutions by articles (I-A), omissions (I-O) and responses semantically non pertinent to the pictures (I-NP) were analyzed, as shown in Table 5.
TABLE 1. Comparison between the rate of correct answers in the production and comprehension tasks for each group, within in each age range - Intra-group analysis.

\begin{tabular}{c} 
Grupo \\
\cline { 2 - 5 }
\end{tabular}

TABLE 2. Comparison between rates of intelligible, unintelligible and absent answers of SG and the CG of inferior age in the production task.

\begin{tabular}{|c|c|c|c|c|c|c|}
\hline \multirow[t]{2}{*}{ Respostas } & \multirow[t]{2}{*}{ Idade } & \multicolumn{2}{|c|}{ GP } & \multicolumn{2}{|c|}{$\begin{array}{l}\text { GC (Idade Inferior } \\
\text { em } 1 \text { Ano) }\end{array}$} & \multirow{2}{*}{$\begin{array}{c}\text { P- } \\
\text { valor }\end{array}$} \\
\hline & & Quantidade & $\%$ & Quantidade & $\%$ & \\
\hline \multirow{3}{*}{ Inteligíveis } & $\begin{array}{c}3 \\
\text { anos }\end{array}$ & 15 & $31,3 \%$ & 77 & $96,3 \%$ & $0,001 *$ \\
\hline & $\begin{array}{c}4 \\
\text { anos }\end{array}$ & 35 & $72,9 \%$ & 79 & $98,8 \%$ & $\underset{0,001 *}{<}$ \\
\hline & $\begin{array}{c}5 \\
\text { anos }\end{array}$ & 29 & $60,4 \%$ & 71 & $98,6 \%$ & <, $<01 *$ \\
\hline \multirow{3}{*}{ Ininteligíveis } & $\begin{array}{c}3 \\
\text { anos }\end{array}$ & 5 & $10,4 \%$ & 1 & $1,3 \%$ & $0,018^{*}$ \\
\hline & $\begin{array}{c}4 \\
\text { anos }\end{array}$ & 8 & $16,7 \%$ & 0 & $0,0 \%$ & $0,001 *$ \\
\hline & $\begin{array}{c}5 \\
\text { anos }\end{array}$ & 9 & $18,8 \%$ & 0 & $0,0 \%$ & $\underset{0,001 *}{<}$ \\
\hline \multirow{3}{*}{ Ausentes } & $\begin{array}{c}3 \\
\text { anos }\end{array}$ & 28 & $58,3 \%$ & 2 & $2,5 \%$ & $0,001 *$ \\
\hline & $\begin{array}{c}4 \\
\text { anos }\end{array}$ & 5 & $10,4 \%$ & 1 & $1,3 \%$ & $0,018 *$ \\
\hline & $\begin{array}{c}5 \\
\text { anos }\end{array}$ & 10 & $20,8 \%$ & 1 & $1,4 \%$ & $0,001 *$ \\
\hline
\end{tabular}

TABLE 3. Comparison between the rate of correct answers of the SG and respective $\mathrm{CG}$ (one year younger) in the production task.

\begin{tabular}{lc|ccccc} 
& \multicolumn{2}{c}{ GP } & \multicolumn{4}{c}{ GC (idade inferior em 1 } \\
Idade & Quantidade & $\%$ & Quantidade & $\%$ & P-valor \\
3 anos & 11 & $22,9 \%$ & 39 & $52,7 \%$ & $0,001^{*}$ \\
4 anos & 11 & $23,9 \%$ & 51 & $65,4 \%$ & $<0,001^{*}$ \\
5 anos & 8 & $17,0 \%$ & 55 & $76,4 \%$ & $<0,001^{*}$
\end{tabular}


TABLE 4. Comparison between the rate of correct answers of the SG and respective $\mathrm{CG}$ (one year younger)in the production task, for each preposition.

\begin{tabular}{ccccc|c|c} 
& & \multicolumn{3}{c}{ GP } & \multicolumn{3}{c}{ GC (Idade Inferior em } & P- \\
P̧ão-Alvosi- & Idade & Ano) & valor \\
com & 4 anos & 4 & $33,3 \%$ & 14 & $70,0 \%$ & $0,043^{*}$ \\
& 5 anos & 2 & $25,0 \%$ & 15 & $88,2 \%$ & $0,002^{*}$ \\
de & 4 anos & 0 & $0,0 \%$ & 12 & $63,2 \%$ & $0,001^{*}$ \\
& 5 anos & 0 & $0,0 \%$ & 10 & $55,6 \%$ & $0,011^{*}$ \\
no(a) & 4 anos & 3 & $50,0 \%$ & 14 & $73,7 \%$ & 0,278 \\
& 5 anos & 4 & $57,1 \%$ & 17 & $100,0 \%$ & $0,004^{*}$ \\
para & 4 anos & 6 & $66,7 \%$ & 13 & $65,0 \%$ & 0,930 \\
& 5 anos & 2 & $33,3 \%$ & 13 & $72,2 \%$ & $0,088^{*}$
\end{tabular}

TABLE 5. Comparison between the rates of errors of the SG and respective $\mathrm{CG}$ (one year younger) in the production task.

\begin{tabular}{|c|c|c|c|c|c|c|}
\hline \multirow{2}{*}{$\begin{array}{l}\text { Tipo } \\
\text { de } \\
\text { Erros }\end{array}$} & \multirow[t]{2}{*}{ Idade } & \multicolumn{2}{|c|}{ GP } & \multicolumn{2}{|c|}{$\begin{array}{c}\text { GC (Idade Inferior em } \\
1 \text { Ano) }\end{array}$} & \multirow[t]{2}{*}{ P-valor } \\
\hline & & Quantidade & $\%$ & Quantidade & $\%$ & \\
\hline \multirow{3}{*}{$\mathrm{I}-\mathrm{OP}$} & 3 anos & 0 & $0,0 \%$ & 16 & $21,6 \%$ & $\stackrel{<}{<}$ \\
\hline & 4 anos & 4 & $8,7 \%$ & 16 & $20,5 \%$ & $0,084^{*}$ \\
\hline & 5 anos & 7 & $14,9 \%$ & 11 & $15,3 \%$ & 0,954 \\
\hline \multirow{3}{*}{ I-A } & 3 anos & 0 & $0,0 \%$ & 2 & $2,7 \%$ & 0,251 \\
\hline & 4 anos & 0 & $0,0 \%$ & 0 & $0,0 \%$ & $-x-$ \\
\hline & 5 anos & 5 & $10,6 \%$ & 0 & $0,0 \%$ & $0,005^{*}$ \\
\hline \multirow{3}{*}{$\mathrm{I}-\mathrm{O}$} & 3 anos & 4 & $8,3 \%$ & 7 & $9,5 \%$ & 0,832 \\
\hline & 4 anos & 18 & $39,1 \%$ & 5 & $6,4 \%$ & $\underset{0,001 *}{<}$ \\
\hline & 5 anos & 8 & $17,0 \%$ & 3 & $4,2 \%$ & $0,018^{*}$ \\
\hline \multirow{3}{*}{ I-Imp } & 3 anos & 0 & $0,0 \%$ & 7 & $9,5 \%$ & $0,028 *$ \\
\hline & 4 anos & 0 & $0,0 \%$ & 1 & $1,3 \%$ & 0,441 \\
\hline & 5 anos & 0 & $0,0 \%$ & 0 & $0,0 \%$ & $-x-$ \\
\hline
\end{tabular}

Children from the CG substituted more one preposition for another than children from the SG, in all ages considered. However, while the CG showed a decrease on the number of these types of errors as age increased, the SG had the exact opposite performance, that is, SG children showed an increase on the number of substitution errors with the increase of the age. Thus, the proportional difference between the groups, which had a great statistical significance in the comparison SG 3 years X CG 2 years, gradually decreased, until it was non-existent, between the older groups. Moreover, 5 -year-old children from the SG omitted and substituted more the prepositions for articles than the children one year younger from the CG.

Analysis of the comprehension task

At first, the rate of correct answers were compared between $\mathrm{SG}$ and $\mathrm{CG}$ children (one year younger) (Table 6).

Children from the SG had a rate of correct answers statistically similar to that of children from the $\mathrm{CG}$ in all ages.

A few types of responses established semantic relations between verbs-prepositions and the subsequent nouns that could also be considered appropriate (i.e. the teacher sat on the... bicycle instead of chair). Even though these responses were computed as errors, they were classified as appropriate errors. Thus, the total number of appropriate errors (among the total number of general errors) was compared between SG and CG (one year younger) (Table 7).

From the total number of errors presented by each group, only 2-year-old CG children had more appropriate errors than 3-year-old SG children, with significant statistical difference.

TABLE 6. Comparison between the rate of correct answers of SG and CG children (one year younger) in the comprehension task.

\begin{tabular}{l|cccccc} 
& \multicolumn{3}{|c}{ GP } & \multicolumn{4}{c}{ GC (Idade Inferior em 1 } \\
Idade & Ano) & P-valor \\
& Quantidade & $\%$ & Quantidade & $\%$ & \\
3 anos & 27 & $56,3 \%$ & 49 & $61,3 \%$ & 0,577 \\
4 anos & 30 & $62,5 \%$ & 50 & $62,5 \%$ & 1,000 \\
5 anos & 37 & $77,1 \%$ & 61 & $84,7 \%$ & 0,289
\end{tabular}


TABELA 7. Comparison between the rate of appropriate errors of SG and CG children (one year younger) in the comprehension task.

\begin{tabular}{lcccc|c} 
& \multicolumn{3}{c}{ GP } & \multicolumn{3}{c|}{ GC(Idade Inferior em 1 } & \multirow{2}{*}{ Ano) } & P-valor \\
Idade & Quantidade & $\%$ & Quantidade & $\%$ & \\
& 3 & $15,0 \%$ & 17 & $54,8 \%$ & $0,004^{*}$ \\
4 anos & 3 & $33,3 \%$ & 13 & $43,3 \%$ & 0,493 \\
5 anos & 6 & $30,0 \%$ & 3 & $27,3 \%$ & 0,890 \\
\hline
\end{tabular}

\section{Discussion}

The data obtained from the comparison of the performances in the production and comprehension tasks shall be interpreted beforehand, for they suggest an interesting discussion. Regarding language development, the linear evolution of the performance within the age range considered indicates an increasing appropriation of certain abilities, either for organic maturational reasons or for a supposed hierarchical sequence of acquisition. The grammatical abilities analyzed in this study, involving the mastering of prepositions, seemed to respect this growing evolution, given that the subjects from the $\mathrm{CG}$ showed an increase of the rate of correct answers, in both tasks, with the age. However, this same relation can only be observed, among children from the SG, in the comprehension task.

Children with SLI had better performance in the comprehension rather than the production task, as described in literature, which reinforces that this language disorder affects mainly the expression abilities (Kamhi, 1998; Dale et al., 2003; CastroRebolledo et al., 2004). These findings, however, are usually the product of studies carried out with tasks of recognition of individual lexical items, that is, recognition of nouns, verbs and adjectives not included in phrasal contexts. The prepositions' comprehension task demands, at least, the understanding of the semantic and syntactic relations between verbs and prepositions, and therefore needs knowledge, even if primitive, of the language's grammar and syntax. If children with SLI showed similar performance to CG subjects, although late, regarding quantity of correct answers and quality of errors, it is possible to infer that they can at least map these semantic and syntactic relations between verbs and their complements, even though they were not able to use it.

Production is really a more complex task, for it involves sophisticated language abilities: it is necessary to choose the ideal grammatical and syntactic structure to represent the relations linked to the message; to evoke the desired words in the mental lexicon; to put phonological elements in temporal order; to program the motor sequence of articulatory gestures; and to keep all these information in the short-term memory while the sentence is being produced (Bishop, 1992). The establishment or mapping of semantic and syntactic relations constitutes only the initial stage of this complex process.

To interpret the results of the production of prepositions, it is necessary to first observe the type of answer children carried out during development. When they presented responses, mainly, unintelligible, 3-year-old children from the SG evidenced the phonological deficits manifested in SLI (Befi-Lopes and Palmieri, 2000; Befi-Lopes et al., 2003). The development and systematization of the phonological system allowed to detect, in 4 and 5 year-old subjects, an error pattern distinct from typical development, emphasizing the deficit in the elaboration of the syntactic structure, as described by Bishop (2000).

Whereas children seem to migrate among the different subgroups of SLI during their development (Crespo-Erguílaz and Narbona, 2003), this change in the pattern of responses reflects the evolution in language development and the transition in the area of greater deficit, as expected.

Children with SLI showed a significant lower rate of correct answers than their peers from the CG in every preposition studied, without any influence from lexical characteristics of each preposition in their performance. This suggests that, even though SLI children have produced in greater proportion the propositions in/on/at and to, which seem to arise earlier in development for being cognitively simpler (Grela et al., 2004) and excessively used by adults (King and Normington, 
1999), even the use of these prepositions is difficult for them. These findings corroborate those of Grela et al. (2004), who observed a more accurate use of "locative" (in/on/at) rather than "dative" (to) prepositions, although the use of such prepositions by SLI children is below the use that children with the same linguistic age make of them. However, the justification pointed out by these authors to explain the divergence of their findings to Watkins and Rice's (1991) does not account for the findings of the present study. The verbs used here were either indirect transitive (demand an indirect object, which is, therefore, obligatory and strongly associated to the verb) or intransitive (allow complements, characterized by the adjunct express notions of place, mean, company, among others).

The fact is that the SG's performance was statistically worse when compared to the CG one year younger for all prepositions following both types of verbs, indistinctively. Besides, in the prepositions' comprehension task, both indirect transitive and intransitive verbs also occurred, and SLI children showed satisfactory performance, although late, proving to understand the semantic and syntactic relations between verbs and prepositions.

The poor performance of children from the SG can be explained from another theoretical perspective. Children, in the beginning of language development, have a global comprehension of information, that is, they associate the meaning of the message to the specific context in which it occurs. As they comprehend information based on its phrasal structure rather that the words themselves, children base their communication in the reproduction of familiar phrasal structures, without spontaneously elaborating their sentences. For the need to obtain a more economic language model that would allow the complete and original expression of their ideas, children observe, learn and generalize linguistic rules, which determine the language mastering (Akhtar, 1999; Tomasello, 2000). However, SLI children have difficulties in comprehending and generalizing such rules, and stay for a long period in the primitive model of language acquisition (Bishop, 1992).

Considering the use of prepositions based on this theoretical perspective, it is logic to infer that children in this sample would have better production of words inserted in phrasal models frequently produced by adults. This affirmative, besides explaining the worse general performance of children from the SG in the production task, also provides subsidies for a more detailed analysis. According to King and Normington (1999), some idiomatic expressions commonly used by adults contain the prepositions in/on/at and to, which, coincidentally, were the most used by SLI children. Thus, while they still seem to be ruled by the use of set phrases, even at 5 years old, typically developing children showed to elaborate phrases based on grammatical/syntactic processing.

The errors presented by children from the CG were characterized, at 4 years old, primordially by the omission of prepositions, and, at 5 years old, by the substitution of one preposition for another or for an article and by their omission, in very similar proportions. That indicates that children with SLI, at first, not even have knowledge about the linguistic structure they must select to complete the sentences. Only from 5 years on, they begin to be sensitive to the use of an essential linguistic element, from a grammatical point of view, in sentences - the prepositions. Grela et al. (2004) observed that children with SLI had more substitution (for another preposition) than omission errors. However, the sample of this study was composed by SLI children with ages ranging from 4 to 7 years old, all gathered in the same group. If the beginning of this understanding by children starts at 5 years old, as observed in this study, it is possible that the performance of 6 and 7-year-old children has masked that of younger children and, in this way, diluted the group.

It's important that other studies be carried out aiming to analyze the production of prepositions in a greater age range, in order to dwell on some aspects of the linguistic development of children with SLI, that is, how the language manifestations of these children evolve.

\section{Conclusion}

The results of this study provided relevant information to scientific knowledge regarding use and comprehension of prepositions by children with SLI. It was observed, as expected, that, for these children, the production of prepositions is a considerably harder task than their comprehension. The hypothesis that SLI children would have a worse general performance in both tasks when compared to the CG was also confirmed.

However, while children from the SG showed a similar pattern to the $\mathrm{CG}$, although late, in the comprehension task, there was a great performance discrepancy in the production task, evidencing a greater expressive deficit in children with SLI and 
reinforcing the initial predictions of this study. Finally, the errors pattern presented by SLI children, in the prepositions' production task, were different from the previously hypothesized. Children with this diagnosis still showed both omission and substitution errors (both by articles and other prepositions) at 5 years old.

Thus, up to this age, children with SLI demonstrated to have a rather restrict knowledge regarding the linguistic structures to be selected for a phrasal elaboration. These findings suggest a grammatical failure, manifested by a linguistic elaboration that uses, mainly, words with strong meanings, but lacking grammatical particles that make the connection of phrases or words in a sentence.

\section{References}

AKHTAR, N. Acquiring basic word order: evidence for data-driven learning of syntactic structure. Journal of Child Language, v. 26, n. 2, p. 339-356, 1999.

BEDORE L. M.; LEONARD, L. B. Grammatical morphology deficits in spanish-speaking children with specific language impairments. Journal of Speech, Language and Hearing Research, v. 44, n. 4, p. 905-924, 2001.

BEFI-LOPES, D. M.; GÂNDARA, J. P.; ARAÚJO, K. Aquisição do sistema fonológico em crianças com alteração do desenvolvimento da linguagem. Pró-Fono Revista de Atualização Científica, v. 15, n. 1, p. 19-30, 2003.

BEFI-LOPES, D. M.; PALMIERI, T. M. Análise dos processos fonológicos utilizados por crianças com alteração do desenvolvimento da linguagem. Jornal Brasileiro de Fonoaudiologia, v. 1, n. 4, p. 48-58, 2000.

BEFI-LOPES, D. M.; RODRIGUES, A. Verificação do vocabulário nas alterações do desenvolvimento de linguagem. Jornal Brasileiro de Fonoaudiologia, v. 2, n. 8, p. 183-190, 2001.

BISHOP, D. V. M. The underlying nature of specific language impairment. Journal of Child Psychology and Psychiatry, v. 33, n. 1, p. 3-66, 1992.

BISHOP, D. V. M. How does the brain learn language? Insights from the study of children with and without language impairment. Developmental Medicine \& Child Neurology, v. 42, n. 2, p. 133-142, 2000.

BISHOP, D. V. M. Genetic and environmental risks for specific language impairment in children. International Journal of Pedriatic Otorhinolaryngology, v. 67, 1, p. S143-S157, 2003. Suplemento.

BORTOLINI, U.; LEONARD, L. B. Phonology and children with specific language impairment: status of structural constraints in two languages. Journal of Communication Disorders, v. 33, n. 2, p. 149-150, 2000.

CASTRO-REBOLLEDO, R.; GIRALDO-PRIETO, M.; HINCAPIÉ-HENAO, L.; LOPERA, F.; PINEDA, D. A. Transtorno específico del desarollo del lenguaje: una aproximación teórica a su diagnóstico, etiologia y manifestaciones clínicas. Revista de Neurologia, v. 39, n. 12, p. 1173-1181, 2004.

CHOUDHURY, N.; BENASICH, A. A family aggregation study: the influence of family history and other risk fators on language development. Journal of Speech, Language and Hearing Research, v. 46, n. 2, p. 261-272, 2003.

CORRÊA, L. M. S.; FREITAS, M. C.; LIMA, C. M. C. Crianças com queixas de linguagem e procedimentos usuais de avaliação de habilidades lingüísticas. Calidoscópio, v. 1, n. 1, p. 43-68, 2003.

CRESPO-EGUÍLAZ, N.; NARBONA, J. Perfiles clínicos evolutivos y transiciones en el espectro del transtorno específico del desarrollo del lenguaje. Revista de Neurología, v. 36, 1, p. S29-S35, 2003. Suplemento.

DALE, P. S.; PRICE, T. S.; BISHOP, D. V. M.; PLOMIN, R. Outcomes of early language delay: I. predicting persistent and transient language difficulties at 3 and 4 years. Journal of Speech, Language and J. Hearing Research, v. 46, n. 3, p. 544-560, 2003.

FEY, M. E.; EADIE, P. A.; DOUGLAS, J. M.; PARSONS, C. L. Profiles of grammatical morphology and sentence imitation in children with specific language impairment and Down Syndrome. Journal of Speech, Language and Hearing Research, v. 45, n. 4, p. 720-732, 2002.

GRELA, B.; RASHITI, L.; SOARES, M. Dative prepositions in children with specific language impairment. Applied Psycholinguistics, v. 25, n. 4, p. 467-480, 2004.

KAMHI, A. G. Trying to make sense of developmental language disorders. Language, Speech and Hearing Services in Schools, v. 29, p. 35-44, 1998.

KING, D.; NORMINGTON, J. Regular versus randomized sentences, Nouns versus prepositions, and assimilation in salience. The Journal of General Psychology, v. 126, n. 2, p. 177-183, 1999.

LEONARD, L. B.; EYER, J. A.; BEDORE, L. M.; GRELA, B. G. Three accounts of the grammatical morpheme difficulties of english-speaking children with specific language impairment. Journal of Speech, Language and Hearing Research, v. 40, n. 4, p. 741-753, 1997. 
MAILLART, C.; SCHELSTRAETE, M. A.; HUPET, M. Phonological representations in children with SLI: a study of french. Journal of Speech Language and Hearing Research, v. 47, n. 1, p. 187-198, 2004.

MCGREGOR, K. K.; NEWMAN, R. M.; REILLY, R. M.; CAPONE, N. C. Semantic representation and naming in children with specific language impairment. Journal of Speech, Language and Hearing Research, v. 45, n. 5, p. 998-1014, 2002.

O'BRIEN, E. K.; ZHANG, X.; NISHIMURA, C.; TOMBLIN, J. B.; MURRIA, J. C. Association of specific language imparment (SLI) to the region of 7q31. American Journal of Human Genetics, v. 72, n. 6, p. 1536-1543, 2003.

STANTON-CHAPMAN, T. L.; CHAPMAN, D. A.; BAINBRIDGE, N. L.; SCOTT, K. G. Identification of early risk factors for language impairment. Research in Development Disabilities, v. 23, n. 6, p. 390-405, 2002.
TOMASELLO, M. Do young children have adult syntactic competence? Cognition, v. 74, n. 3, p. 209-253, 2000.

WATKINS, R. V.; RICE, M. L Verb particle and preposition acquisition in language-impaired preschoolers. Journal of Speech and Hearing Research, v. 34, n. 5, p. 1130-1141, 1991.

WINDFUHR, K. L.; FARAGHER, B.; CONTI-RAMSDEN, G. Lexical learning skills in young children with specific language impairment (SLI). International Journal of Language and Communication Disorders, v. 37, n. 4, p. 415-432, 2002.

WULFECK, B.; BATES, E.; KRUPA-KWIATKOWSKI, M.; SALTZMAN, D. Grammaticality sensitivity in children with early focal brain injury and children with specific language impairment. Brain and Language, v. 88, n. 2, p. 215-28, 2004.

\section{Appendix 1}

\section{PRODUCTION}

\section{Training}

The mother is playing... [with the child]

The man is traveling... [by motorcycle]

The boy is jumping... [in the pool]

The dog is going... [to the house]

Test

The girl is playing... [ with the dog]

The boy is going... [by bycicle]

The boys are climbing... [on the tree]

The men are going... [to church]

The man is walking... [with the dog]

The boy is going... [by skate]

The man is falling... [in the hole]

The man is going... [to the building]

Correct
$($ )
$($ )
$($ )
$($ )
$($ )
$($ )
$($ )
$($ )
$($ )
$($ )
$($ )
$($ )

Incorrect
$($ )
$($ )
$($ )
$($ )
$($ )
$($ )
$($ )
$($ )
$($ )
$($ )
$($ )
$($ )


Appendix 2

Analysis Protocol for the Prepositions' Production Task

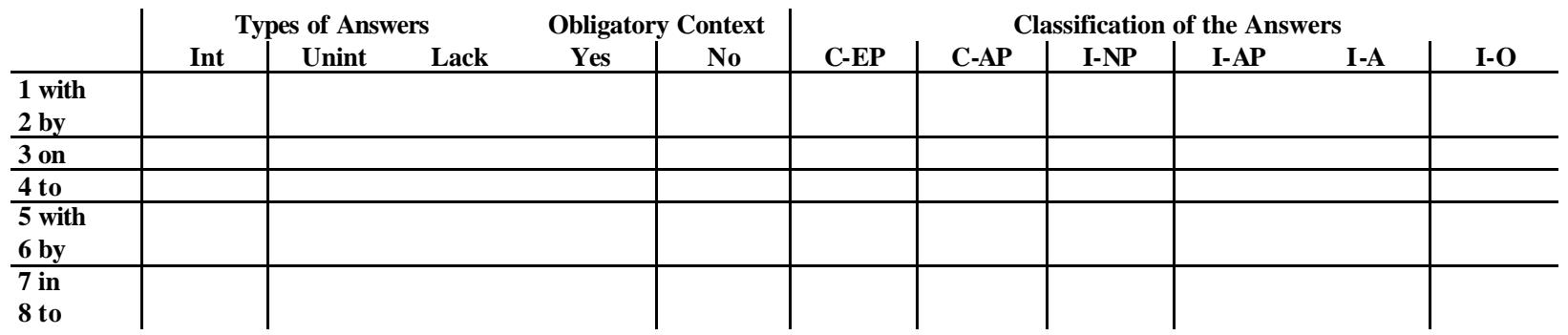

Int - Intelligible answers

Unint - Unintelligible answers

Lack - Lack of answers

C-EP - Correct, and used the expected preposition

C-AP - Correct, but used another preposition

I-NP- Incorrect (non pertinent to the picture), but syntactically acceptable

I-AP - Grammatically incorrect, and used another preposition

I -A - Grammatically incorrect, and used an article

I -O - Grammatically incorrect, and ommited the preposition

\section{If I-AP, I-A ou I-O:}

- $\quad$ Substituted with by

- $\quad$ Substituted by by

in $\quad$ of the 2 possibilities

- $\quad$ Substituted in/on/at by

- Substituted to by in of the 2 possibilities

in of the 2 possib ilities

in of the 2 possibilities

The girl is playing...

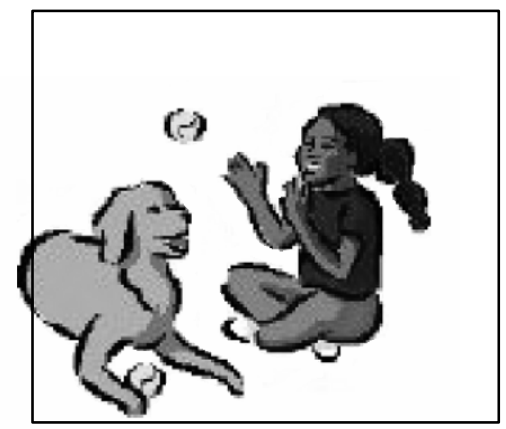


Transcription Protocol for the Prepositions' Comprehension Task

\begin{tabular}{|c|c|c|c|c|}
\hline COMPREHENSION & $\begin{array}{c}\text { Object } \\
\text { (in/on/at) }\end{array}$ & $\begin{array}{l}\text { Place } \\
\text { (to) }\end{array}$ & $\begin{array}{l}\text { Person } \\
\text { (with) }\end{array}$ & $\begin{array}{l}\text { Vehicle } \\
\text { (by) }\end{array}$ \\
\hline \multicolumn{5}{|l|}{ Training } \\
\hline The man slept at the... & Bed & House & Woman & Motorcycle \\
\hline The man went to the $\ldots$ & Bed & House & Woman & Motorcycle \\
\hline The man fought with the... & Bed & House & Woman & Motorcycle \\
\hline The man travelled by... & $\mathrm{Bed}$ & House & Woman & Motorcycle \\
\hline \multicolumn{5}{|l|}{ Test } \\
\hline The teacher sat on the $\ldots$ & Chair & School & Student & Bicycle \\
\hline The teacher went by... & Chair & School & Student & Bicycle \\
\hline The doctor went to the ... & Paper & Hospital & Patient & Airplane \\
\hline The doctor spoke with the... & Paper & Hospital & Patient & Airplane \\
\hline The boy wrote in the... & Notebook & Park & Man & Car \\
\hline The boy went by... & Notebook & Park & Man & $\mathrm{Car}$ \\
\hline The woman went to the & Bench & Building & Groom & Truck \\
\hline The woman married with the & Bench & Building & Groom & Truck \\
\hline
\end{tabular}


Appendix 4

Analysis Protocol for the Prepositions' Comprehension Task

\begin{tabular}{|c|c|c|c|c|c|c|c|c|}
\hline $\begin{array}{c}\text { Answer } \\
\text { Correct } \\
\text { Substitution } \\
\end{array}$ & 1 on & 2 by & 3 to & 4 with & 5 in & 6 by & 7 to & 8 with \\
\hline Lack of answer & & & & & & & & \\
\hline
\end{tabular}

- With - substituted person by

in ___ of the 2 possibilities

- By-substituted vehicle by in of the 2 possibilities

- At/in/on - substituted object by in of the 2 possibilities

- $T o$ - substituted place by in of the 2 possibilities

\section{Exemple of a board from the Prepositions' Comprehension task}

The teacher sat at the...

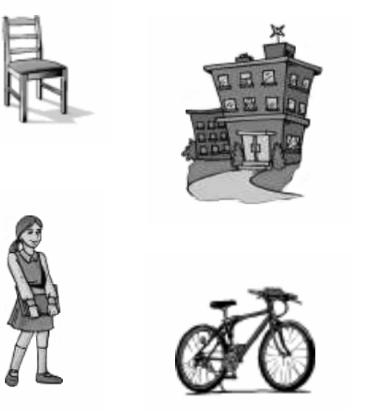

Endereço para correspondência:

Marina Leite Puglisi

R. João Alexandre Rochadel, 76 - São Paulo - SP - CEP: 04565-010. 